\title{
Factors Contributing to Teachers' Use of Computer Technology in the Classroom
}

\author{
Abbas Pourhosein Gilakjani \\ Lahijan Branch, Islamic Azad University, Lahijan, Iran \\ *Corresponding Author: s_m_a57@yahoo.com
}

Copyright $(2013$ Horizon Research Publishing All rights reserved.

\begin{abstract}
There are many factors for teachers to use computer technology in their classrooms. The goal of this study is to identify some of the important factors contributing the teachers' use of computer technology. The first goal of this paper is to discuss computer self-efficacy. The second goal is to explain teaching experience. The third goal is to elaborate inadequate computer technology support. The fourth goal is to investigate teachers' pedagogical practices. The last goal is to examine professional development in computer technology integration.
\end{abstract}

Keywords Computer Self-Efficacy, Teaching Experience, Inadequate Support, Pedagogical Practices, Professional Development

\section{Introduction}

Many researchers agree that technology can be used effectively as a cognitive tool as well as an instructional media. Bruce and Levin [1] suggest that technology can be helpful in classroom by encouraging inquiry, helping communication, constructing teaching products, and assisting students' self-expression. According to Snelbecker [2], it is impossible not to pay attention to the significant impact of technology when discussing instruction, education, or training issues.

The use of computers in education opens a new area of knowledge and offers a tool that has the potential to change some of the existing educational methods. The teacher is the key to the effective exploitation of this resource in the educational system. As computer use continues to increase in society, teachers must also prepare for the use of computers within the classroom [3].

There are many factors that encourage a teacher to use computer technology in his/her classroom. These factors include computer technology training, computer self-efficacy, personal computer technology use, positive teacher beliefs and attitudes towards computer technology, access to professional development in the computer technology and knowledge and experience. All of these factors are important in motivating a teacher to use computer technology. However, using computer technology in the classroom by itself is not effective unless the teacher has a theory to model in instruction with [4].

In this paper, the researcher explains computer self-efficacy, teaching experience, inadequate computer technology support, teachers' pedagogical practices and professional development in computer technology integration.

\section{Computer Self-Efficacy}

According to Compeau and Higgins [5], computer self-efficacy is the judgment of one's capability to use a computer. They stated that an individuals' use of technology was influenced by their self-efficacy and that participants who had higher self-efficacy beliefs used computers more than those who had less self-efficacy beliefs.

Individuals with higher computer self-efficacy beliefs see themselves as able to use computer technology. Those with lower computer self-efficacy beliefs become more disappointed and anxious when working with computer technology and hesitate to use computer technology when they face problems [5].

Compeau and Higgins [5] said that computer self-efficacy has an important effect on individuals' expectations about using computer technology and individuals who were not competent in using computer technology tried not to use it.

Teachers' computer self-efficacy is an important element in identifying their computer technology use [6]. Computer self-efficacy in pre-service teachers had a significant impact on their ability to integrate computer technology use in the classroom $[7,8]$

Teachers' perceived ability to use computer technology was determined by Zhao and Cziko [9]. They said that computer self-efficacy influenced their computer technology use. It was an important factor in identifying the intention to use computer technology [10].

According to Koh and Frick [11], there is a positive relationship between a teacher's computer self-efficacy and computer technology integration in the classroom. A study 
was done by Hernandez-Ramos [12]. He said that students' knowledge of computer technology can question teachers' knowledge because they are frequently using it. Therefore, teachers' roles and students' roles can become interchanged and some teachers may be worried about this situation.

Teachers like to show their authority concerning computer technology in the classroom. In the above study, it was exhibited that fifty-five percent of teachers strongly agreed with the statement "A teacher's knowledge with computers will impact his or her eagerness to integrate technology into the classroom" [12].

Liaw, Huang and Chen [13] said that teachers' computer self-efficacy affects their use of ICT in teaching and learning. Yuen and Ma [14] indicated that the Hong Kong teachers' implementation of ICT was depended on simplicity of computer use and perceived teacher self-efficacy.

Teachers do not use computer technology if they lack confidence [15]. Balanskat et al., [16] stated that fear of failure and lack of ICT knowledge are two important factors for teachers' lack of confidence for integrating ICT into their teaching.

A survey was done by Becta [17]. Results showed that approximately $21 \%$ of the teachers said that lack of confidence impacts their use of computer technology in their classrooms. It has also been stated that teachers who are not skilled in using ICT feel anxious about using it in front of a class of students who know more than they do.

\section{Teaching Experience}

The successful use of computer technology in classrooms is affected by teaching experience $[18,12,19]$. According to Gorder [20], teacher experience is related with the actual use of computer technology. She said that the effective use of computer technology was related to technological comfort levels and the liberty to shape instruction to teacher-perceived student needs.

A study was done by Lau and Sim [21]. It was about the adoption of ICT among 250 secondary school teachers in Malaysia. The obtained results indicated that older teachers used computer technology in their classrooms more than the younger teachers. The reason was that older teachers who have a lot of experience in teaching and skilled in the use of computer technology can integrate ICT into their instruction.

According to Russell, Bebell, O'Dwyer, and O'Connor [22], new teachers who were highly skilled with computer technology more than older teachers did not include ICT in their teaching because of two important reasons. The first reason was that new teachers focused on how to use ICT instead of how to include ICT in their instruction. The second one was that new teachers experienced some challenges in their first years of instruction and spent most of their time to be familiar with the school's curriculum and classroom management.

Russell, O'Dwyer, Bebell and Tao [23] did a survey. It consisted of 3000 teachers. The finding obtained from this survey indicated that the quality of ICT integration was related to the years of teacher service. A qualitative survey was done by Granger, Morbey, Lotherington, Owston and Wideman [24]. It was about the factors contributing to teachers' successful implementation of ICT in Canada. 60 respondents from 12 schools were interviewed.

The results obtained from the above survey did not have any relationship between teachers' teaching experience and experience in the use of ICT. Researchers concluded that ICT skills of teachers and its successful implementation do not clearly predict the integration of ICT (Granger, Morbey, Lotherington, Owston \& Wideman [24]. According to Bordbar [25], teachers who use computer technology are those who have more teaching experiences in their classroom.

\section{Inadequate Computer Technology Support}

One of the other contextual factors that affect the use of computer technology is the inadequate computer technology support in hardware/software. A study was done by Shi and Bichelmeyer [26]. It was indicated that some factors stopped teachers to integrate computer technology. They are the significance of hardware/software and technical support, the lack of effective training, lack of planning for computer technology integration, and lack of material support.

Based on the findings obtained from this study, it was suggested that in order to understand how computer technology is effectively used by teachers, it is essential to investigate the teachers' beliefs and attitudes and the other external factors that may affect their computer technology uses [26].

Teachers who are using computer technologies in their classrooms need sufficient support from computer experts and should learn different software programs. Peer workshops and electronic message boards are the means that can motivate and support teachers who are using computer technologies [27].

Teachers' teaching styles are highly personal and can be impacted by intrinsic and extrinsic factors [28, 29]. One of the important organizational changes that are required for all teachers is to revise their instructional objectives [30].

ICT support in schools helps teachers to use it in teaching without losing time through solving software and hardware problems [31]. The integration of ICT in science teaching needs a computer technician and if this technician is not available, the lack of technical support can cause a lot of problems for teachers [32].

Yilmaz [33] said that in providing schools with hardware and internet connections, it is significant to provide them with technical support concerning repair and maintenance to continue the use of ICT in schools.

According to Tong and Trinidad [34], if there is no technical support for teachers, they will be disappointed to use ICT. Lack of technical support frustrates teachers from 
integrating computer technology in their classrooms.

A study was done by Korte and Husing [31]. It indicated that schools in Britain and the Netherlands have appreciated the importance of technical support to assist teachers to integrate computer technology into their instruction. In their opinion, ICT support in schools affects teachers to use it in their classrooms without wasting their time to solve hardware and software problems.

\section{Teachers' Pedagogical Practices}

The relationship between teachers' teaching methods and computer technology use is one of the other personal factors that should be specially considered. A study was done by Wozney, Venkatesh, and Abrami [35] in Quebec, Canada towards the beliefs of 2,213 teachers in the implementation of computer technology. It was shown that teachers who liked more student-centered methods integrated computer technologies more than the teachers who preferred teacher-centered methods. According to Chen [36] and Judson [37], there isn't any relation between teachers' teaching styles and their computer technology use in the classrooms.

Computer technology has this potential to change teachers' teaching methods. Computer technology allows teachers to move from the role of dispenser of knowledge to a facilitator, allowing the teachers to motivate their students in becoming active learners. Teaching method must change from dispensing information to creating activities that engage students' minds and present intricate problems with many solutions [38].

According to Becker, [39] and Zhao and Cziko [9], teacher's pedagogical methods are very important in affecting teachers' uses of computer technology. Previous research demonstrated that there are some teachers who are exemplary in using computer technology for instruction [40].

Sheingold and Hadley [40] described these teachers as using computer technology in many ways. They reported changes in their teaching methods including presenting more complex materials to students, allowing students to work more independently and becoming more of a coach and facilitator in their instruction.

A study was done by Dexter, Anderson, and Becker [41] in the US. Forty seven teachers took part in this study. Based on the findings obtained from this study, it was exhibited that teachers who adopted more student-centered teaching methods did not believe that computer technology can change their teaching methods.

Another study was done by Chen [36]. Taiwanese teachers supported student-centered method but they also used teacher-centered method. With respect to the different findings that are obtained from different countries, it is recommended that researchers do more research to be able to investigate the relationship between teachers' teaching beliefs, attitudes, and computer technology use.

Pedagogical change is a direct outcome of any computer technology training in which teachers are engaged. Roblyer, Edwards, and Havriluk [42] stated that through integrating computer technology into instruction, teachers become more student-centered and less interested in whole-class instruction. Their activities and projects are more interdisciplinary and more open-ended and students are persuaded to follow creative and appropriate solutions. They stress cooperation and healthy competition.

Dwyer, Ringstaff, and Sandholtz [43] stated that computer technology changes the way teaching occurs. These changes include (1) a move from the teacher as the dispenser of knowledge to the teacher as a facilitator, (2) more opportunity for individualized instruction, (3) spend less time lecturing to the whole class, (4) more comfortable with small-group activities, and (5) team teaching.

Through using computer technology, teacher-centered lectures are moved to more student-centered strategies in which students search for information, analyze data, and draw their own conclusions. This change in pedagogical method is a source of resistance to computer technology. But it can be removed by involving teachers in the change process and training and support for professional development [44].

\section{Professional Development in Computer Technology Integration}

Teachers' computer technology use can be influenced by teacher professional development in computer technology integration. One of the most serious barriers that assist teachers learn how to use computer technology is insufficient teacher training $[45,46,47]$.

In a study that was done by Yang [47], it was exhibited that because of the lack of information technology experts, $46.3 \%$ of the 378 teachers stated that they didn't have any professional development on computer technology integration. The type of training that teachers receive is also very important. Traditional workshops were not useful in assisting teachers learn to integrate computer technology in their classroom.

In order to have a change in teachers' teaching methods, professional development must be content-focused and collaborative and this will certainly lead to students' learning $[48,26,49]$.

Teachers will be able to gain new knowledge from the professional development and integrate it with their classroom teaching methods if enough attention is paid to particular content areas or specific teaching approaches. Teacher professional development should not only pay attention to the particular programs and subject areas and teaching methods but also to the computer technology applications [36, 50, 51, 52].

The efficacy of computer technology integration is actually related to the teaching methods and design principles, rather than computer technology itself Teacher professional development should not only focus on how to 
utilize specific instructional tools, but also on the importance of teaching methods, content, and context [36, 50, 51, 52].

Professional development programs have been used by many educational institutions. They provide teachers with the necessary skills to include computer technology into their teaching and learning and also provide numerous initiatives to urge teachers to use computer technology [53].

Educational technology standards should be met by all candidates who need certification in teacher preparation [54]. The same standards requirements were needed for teachers by [55]. One of the necessary elements for the effective use of computer technology in the classroom is definitely teachers' professional development [56].

Teachers' computer technology knowledge is very important in identifying the integration of ICT, but this is not the necessary condition for the effective use of computer technology. Training programs aid teachers to use computer technology in their teaching and learning [57]. According to Bordbar, [25] teachers who spent more time in professional development activities were more likely to show that they felt well prepared to teach with computer technology.

Brinkerhoff [58] and Diehl [59] showed that professional training programs assist teachers to implement computer technology and transform teaching practices. If training programs have high quality, the period for training will be long, new computer technologies for teaching and learning are provided and teachers are involved in significant activities. Therefore, teachers may integrate computer technology into their instruction [60].

\section{What are the Practical Implications of This Study?}

Based on the review of the related literature, it is concluded that self-efficacy influences the use of computer technology in teaching and learning, teaching experience is related with the real usage of computer technology, lack of technical support stops teachers from using computer technology in their classrooms, computer technology has this potential to change teachers' teaching methods and training helps teachers to implement computer technology and change their teaching practices.

\section{Conclusion}

Five factors contributing teachers' use of computer technology in the classroom were examined in this paper. They were computer self-efficacy, teaching experience, inadequate computer technology support, teachers' pedagogical practices and professional development in computer technology integration. The researcher examined whether the above factors could enhance teachers' use of computer technology. The results of this paper suggested that positive changes can be made in the educational process for teachers to use computer technology. Teachers should use computer technology while they are aware of its purpose, its effectiveness and the factors that lead to the better teaching and learning into their classrooms. The study suggested that continued research needed to be conducted in order to see what is working and what is not working on how to encourage teachers to use computer technology into their classroom instruction.

\section{Acknowledgements}

I thank Seyedeh Masoumeh Ahmadi, Alizadeh, and Babaee for their extensive and insightful discussions and comments on the paper.

\section{REFERENCES}

[1] Bruce, B., \& Levin, J. (2001). Roles for new technologies in language arts: inquiry, communication, construction, and expression. In J. Jenson, J. Flood, D. Lapp, \& J. Squire (Eds.), The handbook for research on teaching the language arts. NY: Macmillan.

[2] Snelbecker, G. E. (1999). Some thoughts about theories, perfection and instruction. In C. Reigeluth Mahwah (Ed.), Instructional-design theories and models . New Jersey/London: Lawrence Erlbaum.

[3] McCannon, M., \& Crews, B.T. (2000). Assessing the technology training needs of elementary school teachers. Journal of Technology and Teacher Education, 8, Issue 2, 111-121.

[4] Fouts, J. T. (2000). Research on computers and education: Past, present and future. Bill and Melinda Gates Foundation. Available: www.portical.org/fouts.pdf

[5] Compeau, D. R., \& Higgins, C. A. (1995). Computer self-efficacy: Development of a measure and initial test. MIS Quarterly, 19(2), 189-211.

[6] Albion, P. R. (2001). Some factors in the development of self-efficacy beliefs for computer use among teacher education students. Journal of Technology and Teacher Education, 9(3), 321-347.

[7] Litterell, A. B., Zagumny, M. J., \& Zagumny, L. L. (2005) "Contextual and psychological predictors of instructional technology use in rural classrooms," Educational Research Quarterly, 29(2), 37-47.

[8] Zhao, Y., Pugh, K., Sheldon, S., \& Byers, J. (2002). Conditions for classroom technology innovations. Teachers College Record, 104, 482-515.

[9] Zhao, Y., \& Cziko, G. A. (2001). Teacher adoption of technology: A perceptual control theory perspective. Journal of Technology and Teacher Education, 9(1), 5-30.

[10] Teo, T. (2009a). Modelling technology acceptance in education: A study of pre-service teachers. Computers and Education, 52(1), 302-312.

[11] Koh, J. H. L., \& Frick, T. W. (2009). Instructor and student 
classroom interactions during technology skills instruction for facilitating pre-service teachers' computer self-efficacy. Journal of Educational Computing Research, 40(2), 211-228.

[12] Hernandez-Ramos, P. (2005). If Not Here, Where? Understanding Teachers' Use of Technology in Silicon Valley Schools. Journal of Research on Technology in Education, 38(1), 39-64.

[13] Liaw, S., Huang, H., \& Chen, G. (2007). Surveying instructor and learner attitudes toward E-learning. Computers and Education, 49(4), 1066-1080.

[14] Yuen, A. H. K., \& Ma, W. W. K. (2008). Exploring teacher acceptance of E-learning technology. Asia-Pacific Journal of Teacher Education, 36(3), 229-243.

[15] Jones, A. (2004). A Review of the Research Literature on Barriers to the Uptake of ICT by Teachers. British Educational Communications and Technology Agency. Retrieved May 20, 2010 from http://www.becta.org.uk.

[16] Balanskat, A., Blamire, R., \& Kafal, S. (2007). A review of studies of ICT impact on schools in Europe. European Schoolnet.

[17] Becta. (2004). A review of the research literature on barriers to the uptake of ICT by teachers. Retrieved June 10, 2010, from http://partners.becta.org.uk/page_documents/research/b arriers.pdf.

[18] Giordano, V. (2007). A professional development model to promote internet integration into P-12 teachers' practice: A mixed method study. Computers in the schools, 24(3/4), 111-123.

[19] Wong, E. M. L. \& Li, S. C. (2008). Framing ICT implementation in a context of educational change: a multilevel analysis. School effectiveness and school improvement, 19(1), 99-120.

[20] [20] Gorder, L. M. (2008). A study of teacher perceptions of instructional technology integration in the classroom. Delta PI Epsilon Journal, 2, 63-76.

[21] Lau \& Sim (2008). Exploring the extent of ICT adoption among Secondary school teachers in Malaysia. International Journal of Computing and ICT Research, 2(2), 19-36. Retrieved Nov 2, 2011 from http://www.ijcir.org/volume2 number2/article 3.pdf.

[22] Russell, M., Bebell, D., O’Dwyer, L. \& O'Connor, K. (2003). Examing teacher technology use: Implications for pre-service and in-service teacher preparation. Journal of Teacher Education, 54(4), 297-310.

[23] Russell, M., O'Dwyer, L. M., Bebell, D., \& Tao, W. (2007). How teachers' uses of technology vary by tenure and longevity. Journal of Educational Computing Research, 37(4), 393-417.

[24] Granger, C. A., Morbey, M. L., Lotherington, H., Owston, R. D., \& Wideman, H. H. (2002). Factors contributing to teachers' successful implementation of IT. Journal of Computer Assisted Learning, 8, 480-488.

[25] Bordbar, F. (2010). English teachers' attitudes toward computer-assisted language learning. International Journal of Language Studies, 4(3), 27-54.

[26] Shi, M., \& Bichelmeyer, B. A. (2007). Teachers' experiences with computers: A comparative study. Educational Technology and Society, 10(2), 180-190.

[27] Dupin-Bryant, P. A. (2004). Variables related to interactive television teaching style: In search of learner-centred teaching styles. International Journal of Instructional Technology and Distance Learning, 1(4), 3-14.

[28] Burnston, J. (2003). Proving IT Works. CALICO Journal, 20(2), 219-226.

[29] Machnaik, J. (2002). Investigating the effect(s) of technology integration on teaching practices that may lead to the development of a community of learners (Electronic version). Saskatoon, SK, Canada: University of Saskatchewan.

[30] Dillon, A., \& Morris, M. G. (1996). User acceptance of information technology: Theories and models. Journal of the American Society for Information Science, 31, 3-32.

[31] Korte, W. B., \& Hüsing, T. (2007). Benchmarking access and use of ICT in European schools 2006: Results from Head Teacher and A Classroom Teacher Surveys in 27 European countries. eLearning Papers, 29(10), 1- 6.

[32] Gomes, C. (2005). Integration of ICT in science teaching: A study performed in Azores, Portugal. Recent Research Developments in Learning Technologies.

[33] Yilmaz, N. P. (2011). Evaluation of the Technology Integration Process in the Turkish Education System. Contemporary Educational Technology, 2(1), 37-54.

[34] Tong, K. P., \& Triniada, S. G. (2005). Conditions and constraints of sustainable innovative pedagogical practices using technology. Journal of International Electronic for leadership in learning, 9(3), 1-27.

[35] Wozney, L., Venkatesh, V., \& Abrami, P. C. (2006). Implementing computer technologies: Teachers' perceptions and practices. Journal of Technology and Teacher Education, 14(1), 173-207.

[36] Chen, C. (2004). Why do teachers not practice what they believe regarding technology integration? Journal of Educational Research, 102(1), 65-75.

[37] Judson, E. (2006). How teachers integrate technology and their beliefs about learning: Is there a connection? Journal of Technology and Teacher Education, 14(3), 581-597.

[38] David, J. L. (1991). Restructuring and technology: Partners in change. Phi Delta Kappan, 73 (1), 37-40, 78-82.

[39] Becker, H. J. (2000a). Findings from the Teaching, Learning, and Computing Survey: Is Larry Cuban Right? Education Policy Analysis Archives, 8(51), 2-32.

[40] Sheingold, K., \& Hadley, M. (1993). Commonalities and distinctive patterns in teachers' integration of computers. American journal of education, 101(3), 261-315.

[41] Dexter, S. L., Anderson, R. E., \& Becker, H. J. (1999). Teachers' views of computers as catalysts for changes in their teaching practice. Journal of Research on Computing in Education, 31, 221-238.

[42] Roblyer, M. D., Edwards, J., \& Havriluk, M. A. (1997). Integrating educational technology into teaching. Upper Saddle River, NJ: Merrill. 
[43] Dwyer, D., Ringstaff, C., \& Sandholtz, J. (1991). Changes in teachers' beliefs and practices in technology-rich classrooms. Educational Leadership, 48(8), 45-52.

[44] Chapman, D. W. (1997). "Improving instructional practice: the teacher's dilemma." In J. Lynch, C. Modgil, S. Modgil, Innovations in delivering primary education, Volume 3 of the Education and Development: Tradition and Innovation series. London: Cassell Publishers.

[45] Bauer, J., \& Kenton, J. (2005). Toward technology integration in the schools: Why it isn't happening. Journal of Technology and Teacher Education, 13(4), 519-546.

[46] Mitchem, K., Wells, D., \& Wells, J. (2003). Effective integration of instructional technologies (IT): evaluating professional development and instructional change. Journal of Technology and Teacher Education, 11(3), 397-414.

[47] Yang, C. Q. (2008). A research study on teacher professional development in technology-rich educational environment. Teacher Professional Development Forum. Retrieved on June 20, 2009 from http://www.ckni.net

[48] Li, G., \& Protacio, M. S. (2010). Best practices in professional development for teachers of ELLs. In G. Li and P. Edwards (Eds.), Best practices in ELL instruction. NY: Guilford Press.

[49] Wei, R. C., Darling-Hammond, L., Andree, A., Richardson, N., \& Orphanos, S. (2009). Professional learning in the learning profession: A status report on teacher development in the United States and abroad. Dallas, TX: National Staff Development Council.

[50] Dudeney, G., \& Hockly, N. (2007). How to teach English with technology? Harlow: Pearson Education Limited.

[51] Parks, S., Huot, D., Hamers, J., \& Lemonnier, F. H. (2003). Crossing boundaries: multimedia technology and pedagogical innovation in a high school class. Language Learning and Technology 7(1), 28-45.

[52] Zhao, Y. (2003). Recent Developments in Technology and
Language Learning: A Literature Review and Meta-analysis. CALICO Journal, 21(1), 7-27.

[53] Sheumaker, F., Slate, J. R., \& Onwuegbuzie, A. J. (2001). The role of In Tech training in the integration of technology into instructional practices among Georgia middle school teachers. Journal of Research on Technology in Education, 33(5). Retrieved January 12, 2003, from http://www.iste.org/jrte/33/5/sheumaker.cfr

[54] International Society for Technology in Education. (2001). Retrieved November 20, 2002, from http://www.iste.org/standards/index.cfm

[55] National Council on the Accreditation of Teacher Education (1997). Technology and the new professional teacher: Preparing for the 21 st century classroom. Retrieved January 5, 2003, from http://www.ncate.org/accred/projects/tech/tech $-21 . h t m$

[56] King, K. P. (2002a). Keeping pace with technology. Cresskill, NJ: Hampton Press.

[57] Sandholtz, J. H., \& Reilly, B. (2004). Teachers, not technicians: Rethinking technical expectations for teachers. Teachers College Record, 106(3), 487-512.

[58] Brinkerhoff, J. (2006). Effects of a long-duration, professional development academy on technology skills, computer self-efficacy and technology integration beliefs and practices. Journal of Research on Technology in Education, 39(1), 22-43.

[59] Diehl, D. E. (2005). A study of faculty-related variables and competence in integrating instructional technologies into pedagogical practices. Unpublished doctoral dissertation. Texas Southern University.

[60] Lawless, K. A., \& Pellegrino, J. W. (2007). Professional development in integrating technology into teaching and learning: Knowns, unknowns, and ways to pursue better questions and answers. Review of Educational Research, 77(4), 575-614. 